\title{
ANASTASIS IN GLIOBLASTOMA, BRAIN CANCER STEM, AND BRAIN STEM CELLS
}

\author{
Melodi Inceboz ${ }^{1}$, Bakiye Goker Bagca ${ }^{2}$, Ayse Caner $^{3}$, Cumhur Gunduz ${ }^{2}$ \\ ${ }^{1}$ Isikkent High School, Izmir, Turkey. \\ ${ }^{2}$ Ege University, Faculty of Medicine, Department of Medical Biology, Izmir, Turkey. \\ ${ }^{3}$ Ege University, Faculty of Medicine, Department of Parasitology, Izmir, Turkey.
}

\begin{abstract}
Address for Correspondence: Bakiye Goker Bagca, E-mail: bakiye.goker.bagca@ege.edu.tr Received: 06.01.2021; Accepted: 08.02.2021; Available Online Date: 04.03.2021

(C) Copyright 2021 by Dokuz Eylül University, Institute of Health Sciences - Available online at https://dergipark.org.tr/en/pub/jbachs
\end{abstract}

Cite this article as: Inceboz M, Goker Bagca B, Caner A, Gunduz C. Anastasis In Glioblastoma, Brain Cancer Stem, And Brain Stem Cells. J Basic Clin Health Sci 2021; 1: 14- 21.

\begin{abstract}
Objective: Anastasis, a process that has been discovered recently, halts apoptosis, and thus, recovers the survival functions of cells. It may be suggested that anastasis is related to cancer progression, especially in cancer stem cells which are responsible for therapy resistance, metastasis, and recurrence. In this study, the investigation of the anastasis phenomena and its effect on stemness related gene expressions of brain cancer-related cells are aimed.

Methods: In this study commercially obtained glioblastoma multiforme (GBM), brain cancer stem cells (BCSC), and brain stem cells (BSC) were used for in vitro models. To induction of apoptosis $4 \%$ ethanolincluding medium was used. Annexin $V$ assay was used for confirmation of apoptotic and anastatic status. Gene expression profile was determined real-time qRT-PCR method and fold changes were calculated by using $2^{-\Delta \Delta C t}$ method. Ingenuity Pathway Analysis was used for the functional pathway and upstream regulatory analysis.

Results: A common decrease in the expression of stemness related genes in GBM cells was determined by real-time qRT-PCR performed on anastatic cells. Although BSCs showed a similar expression profile with GBM cells, all stemness genes were upregulated in BCSCs. Similar to expression profile, the canonical pathways were markedly down-regulated in BSC and GBM, while they were up-regulated in BCSC. Differently, it is determined that the activation of self-renewal in GBM and BCSC, unlike BSC.

Conclusion: We have demonstrated that the inhibition of anastasis may be used to prevent the malignant transformation of healthy stem cells and the aggression of cancerous stem cells. Anastasis may be suggested as a critical mechanism that supports uncurable cancers.
\end{abstract}

Keywords: apoptosis, anastasis, glioblastoma, brain stem cell, brain cancer stem cell, gene expression

\section{INTRODUCTION}

Apoptosis, which is known as type I cell, is the most basic and most researched cell death type that is induced by intracellular or extracellular death signals. This type of regulated cell death includes two separate apoptotic pathways that are intrinsic and extrinsic apoptosis. It is mainly controlled by caspases and BCL2 family member proteins. Its characteristic morphology includes "apoptotic bodies" which are formed by cytoplasmic shrinkage, membrane blebbing, and nuclear condensation ad fragmentation. These bodies have phosphatidylserine "eat-me" signals on their extracellular surface so they may recognizable by 
other cells that are responsible for eliminating apoptotic cells. Apoptosis is an essential way of both maintaining the homeostasis of the multicellular organism and eliminating irreversibly DNA-damaged cells that cause potential harm (1). Until recently, it has been suggested that activation of caspase cascade or cytochrome $\mathrm{C}$ release to the cytoplasm are accepted as "point of no return" and apoptosis is irreversible. However, this assumption is falsified by new researches. It is demonstrated that even though the caspase cascade is initiated, some cells escaped from cell death. To describe this phenomenon, researchers coined the term "anastasis", which means coming back from death in Greek (2). In addition, the role of anastasis is observed not only in apoptosis, but also in other cell death types such as necrosis, pyroptosis, ferroptosis (3). Although anastasis is shown empirically, the underlying molecular mechanisms of this process are yet to be unveiled (2).

Stem cells are the cells that are formed during the embryonic period and the proliferation and differentiation of the cells constitute other cell types. The characteristic features that separate stem cells from other cells are the capability of regeneration, differentiation, and clonality. This feature of stem cells to produce daughter cells that also have the potential to divide and differentiate unlimitedly is termed "stemness". Owing to these abilities, stem cells are capable of maintaining their cell count and increasing the number of differentiated cells by differentiating when necessary (4). The genetic mechanism that controls these properties of stem cells are determined: the genes POU5F1 (OCT4), SOX2, $K L F 4, M Y C$, and NANOG are the main stemness genes that enable normal cells to transform into stem cells (5). In addition, NOTCH and WNT signaling pathways are responsible for cell differentiation in the embryonic period and WNT5A, WNT5B, WNT3A, $F Z D 1$, and $F Z D 2$ genes play role in these pathways that are closely related with stem cells (6).

Stem cells are also an important milestone for the development and progression of malign neoplasms. They take roles in tumor initiation, therapy resistance, invasion, metastasis, and recurrence (7). Glioblastoma multiforme (GBM) is the most aggressive type of brain cancers and cancer stem cells are an important therapeutic target in this type of cancer as well as in other malignancies. Although programmed cell death by inducing apoptosis is the essential target of cancer treatment, it is known that stem cells develop resistance mechanisms against apoptosis and cause poor prognosis (8). In the spot of this information, this study aimed to induce anastasis in GBM, brain cancer stem cells (BCSC), and healthy brain stem cells (BSC), and to investigate the role of stemness genes in this survival process.

\section{METHODS \\ Cell culture}

Commercially obtained BSC (Brain Stem Cell; Celprogen 36109-36), BCSC (Brain Cancer Stem Cell; Celprogen 36110-37), and GBM cells (ATCC HTB-15, U118MG) were used as in vitro models. Cells were cultured in RPMI-1640 medium supplemented with $10 \%$ and $2 \%$ FBS (Biological Industries, 04-121-1B) for glioblastoma and stem cells, respectively. The media were also supplemented with $1 \% \mathrm{mM}$ L-glutamine (Biological Industries Cat. No: 03-020-1B), and 1\% penicillinstreptomycin (Biological Industries Cat. No: 03-031$1 B)$ and the cells were incubated in a cell culture incubator (Thermo Electron Corporation's Class 100) at $37{ }^{\circ} \mathrm{C}, 95 \%$ humidity, and $5 \% \mathrm{CO}_{2}$ until they reach sufficient number and viability.

\section{Apoptosis and anastasis induction}

Apoptosis and anastasis induction was carried out using a previously described protocol by Tang et al (2). The cells were cultured in a six-well plate $3.5 \times 10^{5} /$ $3 \mathrm{ml}$ cells per well for $24 \mathrm{~h}$. At the end of this period, the apoptosis induction media which include $4 \%$ ethanol (Merck, Cat.No: 1070172511) was added to cells. After the $38 \mathrm{~min}$ incubation period, the apoptosis induction media was removed and cells were twice washed with serum-free media. To induce anastasis, cells were incubated in FBS including medium for $6 \mathrm{~h}$. Untreated cells were used as control groups. At the end of each incubation period, cells were tyripsinized for use in annexin $\mathrm{V}$ assay and gene expression analysis.

\section{Annexin V assay}

After the each incubation periods, the media was removed and cells were washed with serum- free media. Cells were tyripsinized and centrifuged at $1200 \mathrm{rpm}$ for $5 \mathrm{~min}$. Supernatant was removed and cells were homogenized in PBS. Cells were centrifuged at $1200 \mathrm{rpm}$ for $5 \mathrm{~min}$. Supernatant was removed and cells were homogenized in $100 \mu \mathrm{l} 1 \times$ annexin $\mathrm{V}$ binding buffer (BD Biosciences, Cat. No: 


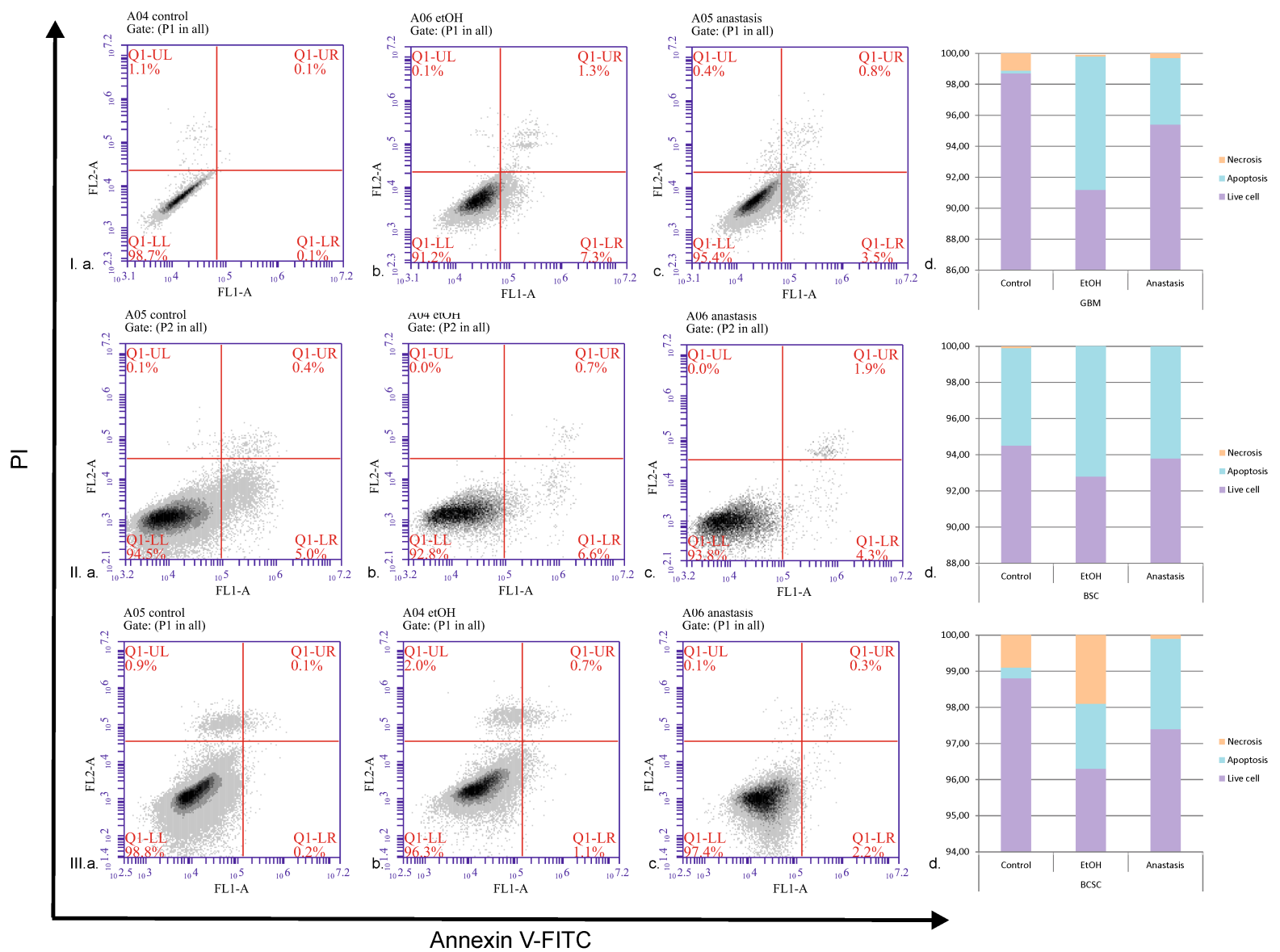

Figure 1. Annexin V results of the three cells; I. GBM, II. BSC, III. BCSC cell types; a.Control, b.EtOH, c.Anastasis groups; d. Apoptotic, necrotic, and lived cell percentages.

556547), $5 \mu \mathrm{l} \mathrm{PI}$ and $5 \mu \mathrm{l}$ FITC Annexin V (BD Biosciences, Cat. No: 556547) were added to each group and cells were incubated at $37^{\circ} \mathrm{C}$ for $15 \mathrm{~min}$. After the incubation period live and dead cells and apoptosis percentage were measured with flow cytometer (BD Accuri C6, BD Biosciences) using FL1 and FL2 channels.

\section{Gene expression analysis}

After the each incubation periods, RNA isolation was performed with RNeasy Plus Mini Kit (Qiagen, Cat. No: 74134). cDNA was synthesized by $\mathrm{RT}^{2}$ First Strand Kit (Qiagen, Cat. No: 330401). Gene expression analysis for the genes WNT5A, POU5F1, WNT5B, MYC, WNT3A, NANOG, FZD1, NOTCH1, FZD2, SMO, SOX2, SRC, SOX10, KLF4 was carried out by using Real-Time qRT-PCR LightCycler 480 Instrument II (Roche) and RT ${ }^{2}$ SYBR Green qPCR Mastermix (Qiagen, Cat. No: 330500) includes DNA Taq polymerase enzyme and SYBR Green dye. RPLPO (Ribosomal protein) and ACTB (B-actin) were used as reference genes. Data analyses were achieved by the $2^{-\Delta \Delta C t}$ method.

\section{Identification of activated regulators and} pathways

It was used the commercial Ingenuity Pathway Analysis (IPA, www.qiagen.com/ingenuity) software for functional pathway and upstream regulatory analysis of differentially expressed genes (DEGs) identified in this study. The analysis results were first uploaded into IPA system for core and comparison analyses, and then overlaid with the global molecular network in the Ingenuity pathway knowledge base. IPA was performed a downstream effect analysis to identify canonical pathways, diseases and functions that are most significant to outcomes ( $p$-value $\leq 0.01$; $z$-score $\geq 1$ ). The Fisher's exact test was used to estimate the probability of the association between a set of molecules and a function/pathway. The IPA regulation z-score algorithm was used to predict the direction of change. A z-score $\geq 1$ means that a function is significantly increased whereas a z-score $\leq 1$ indicates a significantly decreased function. It was generated a map of the molecular pathway populated by the altered mRNAs. Heatmap analysis was used to demonstrate the expression patterns, and 


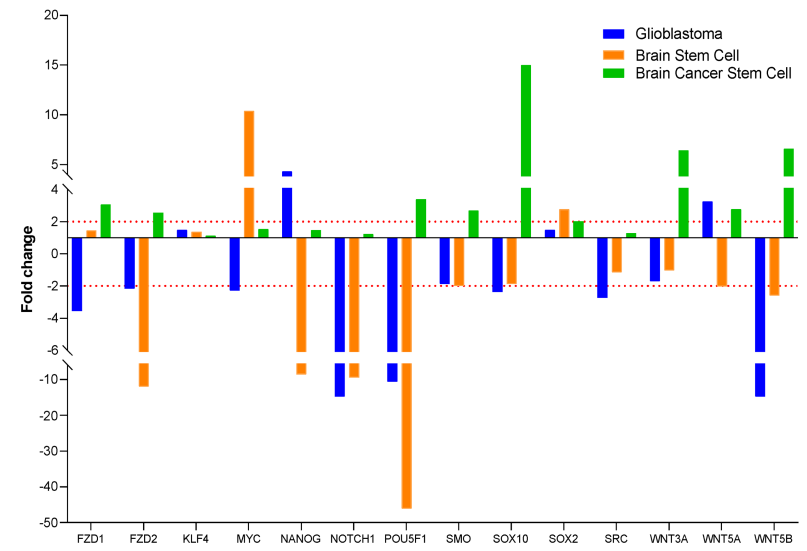

Figure 2.Gene expression changes of the anastatic cells compared to control.

biological functions or diseases for comparison of three cells.

\section{RESULTS}

\section{Removing the apoptosis-inducing factor may} improve cell viability

Annexin $V$ assay was used to confirm the reversal of cell death and the induction of anastasis. Removal of the ethanol-including media increased GBM, BSC, and BCSC cell viability to $4.2 \%, 1.0 \%$, and $1.1 \%$, respectively (Table 1, Figure 1 ).

Anastasis affects expression levels of the stemness-related genes

Anastasis caused downregulation of 8 genes and upregulation of 2 genes in GBM cells and BSCs showed a similar expression profile with GBM cells. But all stemness genes were upregulated in BCSCs (Table 2, Figure 2).
Pathway, upstream regulator and function analyses

IPA core analysis which categorized the DEGs showed that the canonical pathways were markedly down-regulated in BSC and GBM, while they were up-regulated in BCSC. The top enriched categories of canonical pathways with a p-value less than 0.01 are listed in Figure 3. The Human Embryonic Stem Cell Pluripotency pathway was identified as one of the significant pathways by IPA ( $p$ value: 1.38E-17). These pathways showed the activation of selfrenewal in GBM and BCSC unlike BCS (Figure 4). In addition to canonical pathways, DEGs were also categorized to related diseases and functions with a p-value less than $10^{-5}$ are listed in Figure 5 . Upstream Regulator analysis was used to identify upstream transcriptional regulators and were predicted the activated and inhibited of transcription factors as shown in Table 3.

\section{DISCUSSION}

The determination that apoptosis, which is considered to be irreversible, can be reversed in a way that supports cell survival through a mechanism called anastasis is a remarkable subject in cancer research (2). It is known that cancer stem cells are resistant to apoptosis and this constitutes one of the main disadvantages in treatment (8). The potential relationship between anastasis and brain cancer, which was not discussed before, was evaluated especially in terms of stem cells and stemness genes, in this study.
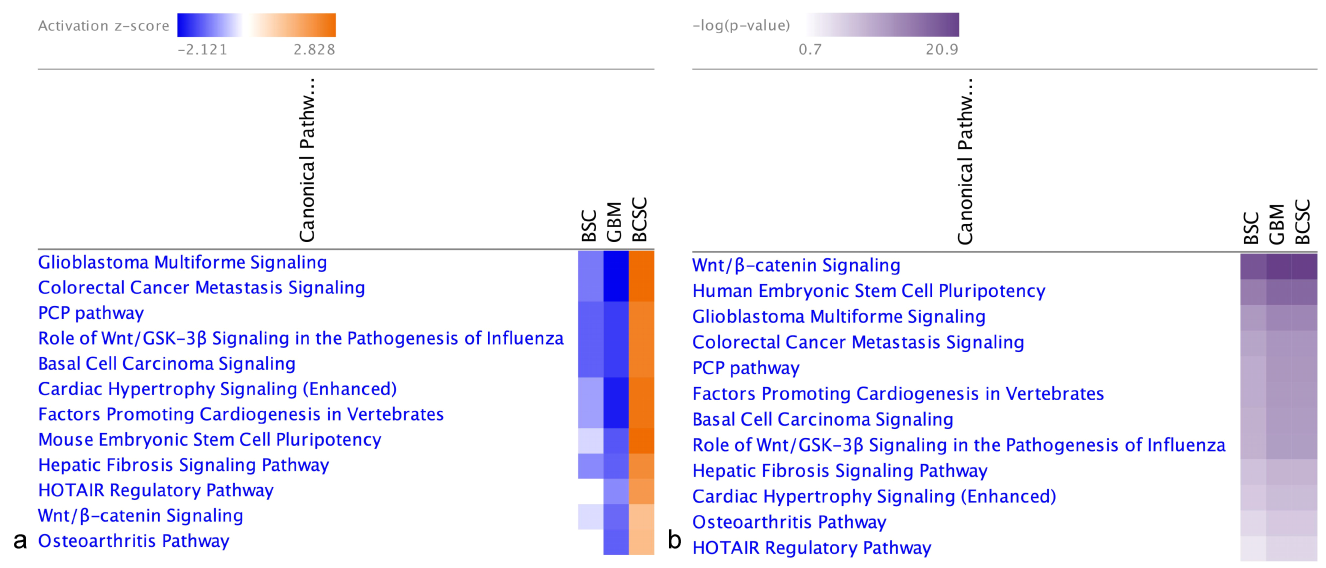

Figure 3: Canonical pathways identified by IPA. Heat map grafts of activation score (absolute z-score $>2$ ) (a), p-value (absolute log p-value>5) (b) in three cell types. 


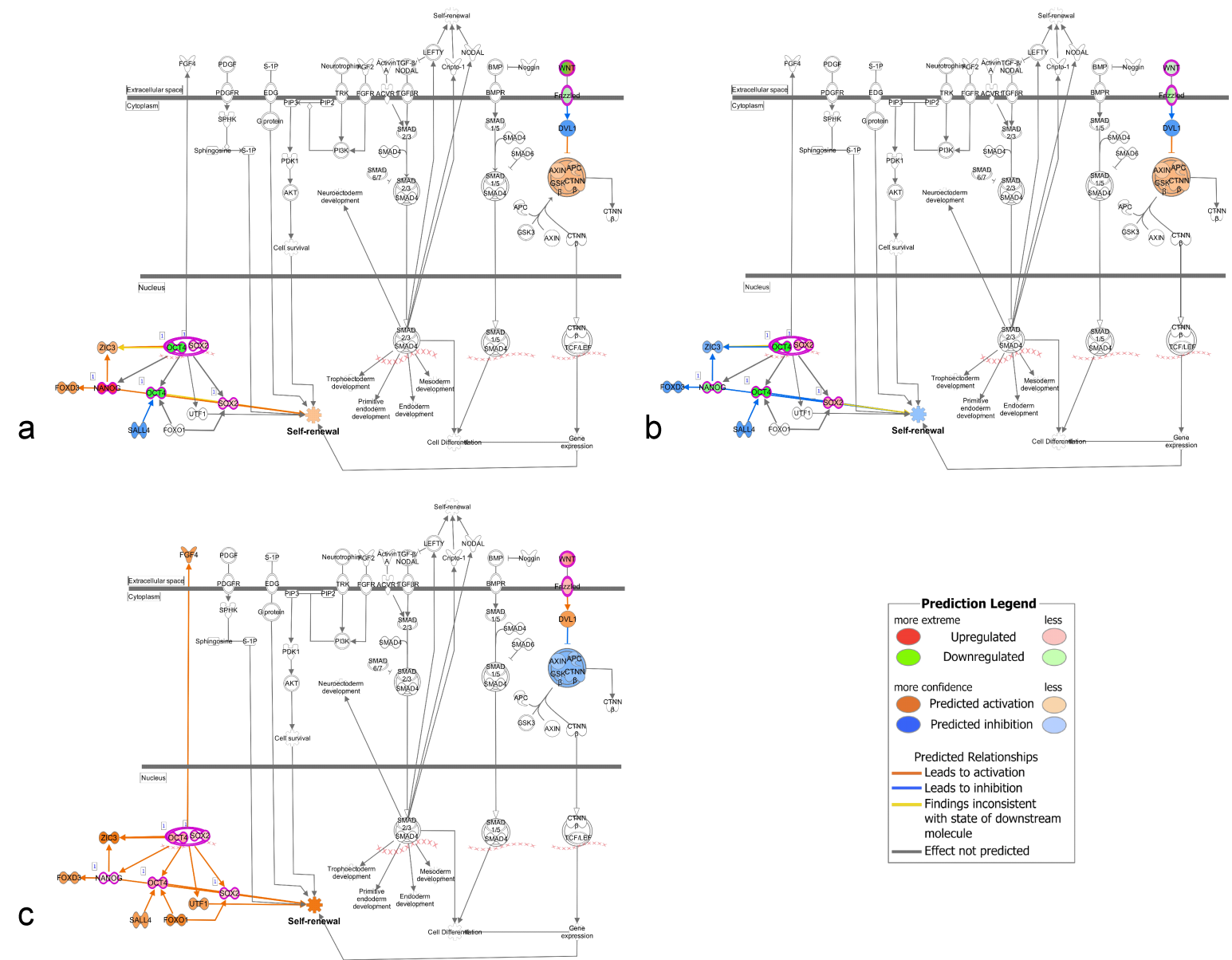

Figure 4. Ingenuity Pathways Analysis summary of anastasis in GBM (a), BSCs (b) and BCSCs (c).

As expected, annexin $V$ assay that was used for proving apoptotic or anastatic status, showed that removing the apoptosis-inducing factor causes an improvement of cell viability (2). When it was evaluated that the gene expression changes of the anastatic cells compared to control, the three cell lines had different expression patterns were determined. Although there are commonalities between GBM and BSC expression profiles, the BCSC expression profile was exactly different. Differences in the expression profile between stem cells, cancer stem cells and cancer cells are expected and acceptable, even if they originate from the same tissue (9). Although it is very common for stem cells and normal cells to have different expression profiles, it is known that the expression profile may also differ between cancerous and non-cancerous stem cells. Genetic alterations acquired during cancer development are the main sources of differences in cells (10). It is expected that cells with different genetic structures will give different genetic responses to common exposures, and the results obtained from your study support this.
Anastasis in GBM cells result in a decrease in the expression of stemness genes in relevance to the control group. FZD1, FZD2, MYC, NOTCH1, POU5F1, SOX10, SRC, and WNT5B genes were downregulated in anastatic GBM cells. This may suggest that the mechanism of anastasis may suppress stemness properties of GBM cells. NANOG and WNT5A upregulation may lead to a more aggressive phenotype of the cells as independently from the stemness feature $(11,12)$. Moreover, these results also indicated that the cells may become stem-like cells by gaining a self-renewal property (13). The canonical pathways which regulate GBM and metastasis signaling were also down-regulated in GBM cells.

Expression of stemness genes in non-cancerous recovered brain stem cells is mainly reduced. Therefore, the occurrence of anastasis in these cells may cause a decrease in their stemness and selfrenewal properties. Additionally, the increase in the gene expression of $M Y C$, a proto-oncogene, after the induction of anastasis, showed that oncogenic transformation may take place in healthy brain stem 

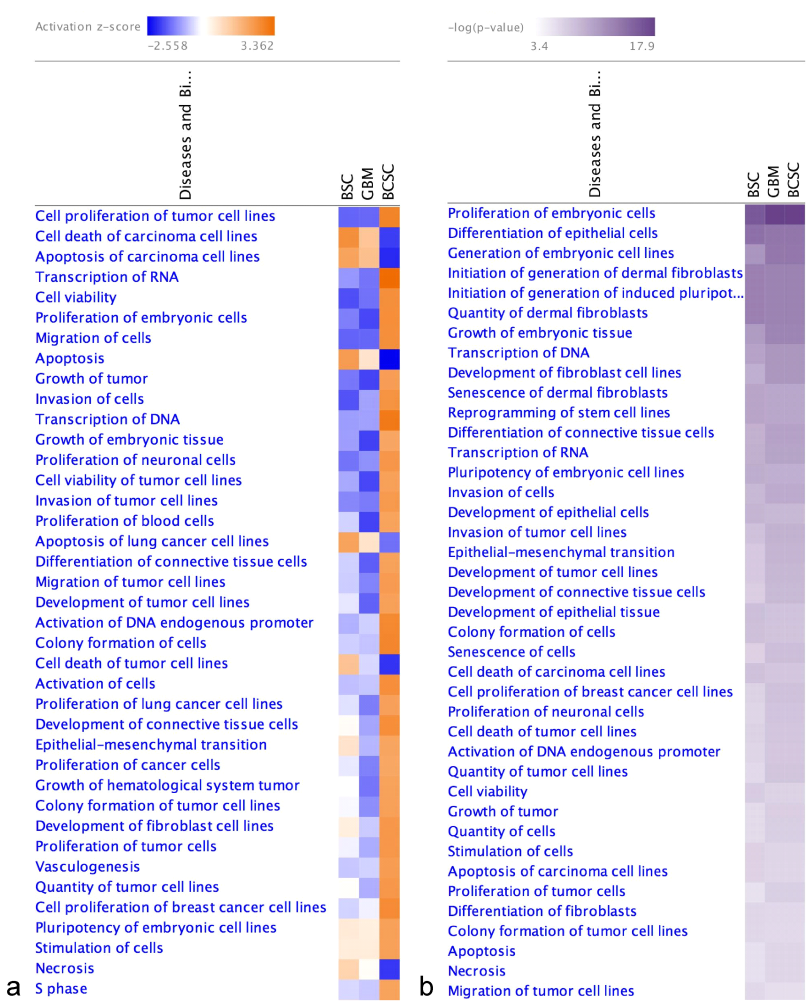

Figure 5: Diseases and Functions in three cell types by comparison analysis. Heat map grafts of activation score (absolute z-score >2) (a), p-value (absolute log p-value>2) (b).

cells (14). MYC gene is one of the critical neural developmental regulators as well as oncogenic transformation of normal cells (15). The GBM and metastasis signaling pathways were also downregulated both BSC and GBM.
Table 1. Apoptotic, necrotic, and lived cell percentages of the GBM, BSC, and BCSCs

\begin{tabular}{ccccc} 
Cell type & Group & $\begin{array}{c}\text { Live cell } \\
\mathbf{( \% )}\end{array}$ & $\begin{array}{c}\text { Apoptosis } \\
\mathbf{( \% )}\end{array}$ & $\begin{array}{c}\text { Necrosis } \\
\mathbf{( \% )}\end{array}$ \\
& Control & 98.70 & 0.20 & 1.10 \\
GBM & EtOH & 91.20 & 8.60 & 0.10 \\
& Anastasis & 95.40 & 4.30 & 0.40 \\
\hline \multirow{3}{*}{ BCS } & Control & 94.50 & 5.40 & 0.10 \\
& EtOH & 92.80 & 7.30 & 0.00 \\
& Anastasis & 93.80 & 6.20 & 0.00 \\
BCSC & Control & 98.80 & 0.30 & 0.90 \\
& EtOH & 96.30 & 1.80 & 2.00 \\
& Anastasis & 97.40 & 2.50 & 0.10 \\
\hline
\end{tabular}

An upward trend in the expression of stemnessassociated genes in brain cancer stem cells was found. Anastasis in cancer stem cells, caused an increase in the expression of stemness genes, and led to a rise both in stemness properties and oncogenic potentials. In addition to stemness the cells also improved their self-renewal capacity which related with poor prognosis (16). Consistent with the results of canonical pathway analysis, many categories of diseases and functions in BSC and GBM were different regulated than BCSC. While proliferation, viability, migration, invasion, transformation, activation of cells and cancer cell, and

Table 2. Gene expression changes of the anastatic cells compared to control (red increase, blue decrease)

\begin{tabular}{lrrrrrr}
\hline \multirow{2}{*}{ Gene } & \multicolumn{2}{c}{ GBM } & \multicolumn{2}{c}{ BSC } & \multicolumn{2}{c}{ BCSC } \\
\cline { 2 - 6 } & Fold Change & p value & Fold Change & p value & Fold Change & p value \\
\hline FZD1 & -3.54 & $<0.000001$ & 1.43 & 0.000055 & 3.04 & $<0.000001$ \\
FZD2 & -2.15 & 0.000011 & -11.92 & 0.000004 & 2.54 & 0.000004 \\
KLF4 & 1.46 & 0.000011 & 1.35 & 0.000069 & 1.11 & 0.000331 \\
MYC & -2.27 & $<0.000001$ & 10.37 & $<0.000001$ & 1.52 & $<0.000001$ \\
NANOG & 4.27 & $<0.000001$ & -8.54 & $<0.000001$ & 1.45 & $<0.000001$ \\
NOTCH1 & -14.77 & $<0.000001$ & -9.35 & $<0.000001$ & 1.21 & 0.000001 \\
POU5F1 & -10.52 & $<0.000001$ & -46.05 & 0.000004 & 3.38 & 0.000001 \\
SMO & -1.85 & 0.000002 & -1.99 & $<0.000001$ & 2.67 & $<0.000001$ \\
SOX10 & -2.37 & 0.000008 & -1.86 & 0.000003 & 14.98 & $<0.000001$ \\
SOX2 & 1.46 & 0.000004 & 2.74 & $<0.000001$ & 2.01 & $<0.000001$ \\
SRC & -2.72 & 0.000001 & -1.14 & 0.006605 & 1.26 & 0.000086 \\
WNT3A & -1.69 & 0.000002 & -1.03 & 0.001757 & 6.39 & $<0.000001$ \\
WNT5A & 3.24 & $<0.000001$ & -2.02 & 0.000002 & 2.74 & $<0.000001$ \\
WNT5B & -14.67 & $<0.000001$ & -2.58 & 0.000002 & 6.57 & $<0.000001$ \\
\hline
\end{tabular}


Table 3: Upstream pathways of the three cell lines

\begin{tabular}{|c|c|c|c|c|c|c|}
\hline & Upstream Regulator & Molecule Type & $\begin{array}{c}\text { Predicted } \\
\text { Activation } \\
\text { State }\end{array}$ & $\begin{array}{l}\text { Activation } \\
\text { z-score }\end{array}$ & $\begin{array}{l}\text { p-value of } \\
\text { overlap }\end{array}$ & Target Molecules in Dataset \\
\hline GBM & RARA & $\begin{array}{l}\text { ligand-dependent } \\
\text { nuclear receptor }\end{array}$ & Inhibited & $-2,233$ & $\begin{array}{l}0,00000 \\
207\end{array}$ & $\begin{array}{l}\text { KLF4, MYC, NANOG, POU5F1, } \\
\text { SOX2 }\end{array}$ \\
\hline \multirow[t]{12}{*}{ BSC } & BMP4 & growth factor & Activated & 2,000 & $\begin{array}{l}1,16 \mathrm{E}- \\
09\end{array}$ & $\begin{array}{l}\text { KLF4, MYC, NANOG, POU5F1, } \\
\text { SOX2, WNT5A }\end{array}$ \\
\hline & STAT3 & $\begin{array}{l}\text { transcription } \\
\text { regulator }\end{array}$ & Activated & 2,204 & $\begin{array}{l}0,00000 \\
107\end{array}$ & $\begin{array}{l}\text { KLF4, MYC, NOTCH1, POU5F1, } \\
\text { SOX2, WNT5A }\end{array}$ \\
\hline & PRMT5 & enzyme & Activated & 2,236 & $\begin{array}{l}4,83 \mathrm{E}- \\
11\end{array}$ & $\begin{array}{l}\text { KLF4, MYC, NANOG, POU5F1, } \\
\text { SOX2 }\end{array}$ \\
\hline & ID1 & $\begin{array}{l}\text { transcription } \\
\text { regulator }\end{array}$ & Activated & 2,213 & $\begin{array}{l}5,74 \mathrm{E}- \\
10\end{array}$ & $\begin{array}{l}\text { MYC, NANOG, NOTCH1, } \\
\text { POU5F1, SOX2 }\end{array}$ \\
\hline & INHBA & growth factor & Activated & 2,000 & $\begin{array}{l}0,00000 \\
523\end{array}$ & KLF4, NANOG, POU5F1, SOX2 \\
\hline & CD44 & other & Activated & 2,219 & $\begin{array}{l}1,85 \mathrm{E}- \\
09\end{array}$ & $\begin{array}{l}\text { MYC, NANOG, POU5F1, SOX2, } \\
\text { SRC, WNT5A }\end{array}$ \\
\hline & POU5F1 & $\begin{array}{l}\text { transcription } \\
\text { regulator }\end{array}$ & Activated & 2,358 & $\begin{array}{l}5,91 \mathrm{E}- \\
10\end{array}$ & $\begin{array}{l}\text { KLF4, MYC, NANOG, POU5F1, } \\
\text { SOX2, SRC, WNT5A }\end{array}$ \\
\hline & TNFRSF11A & $\begin{array}{l}\text { transmembrane } \\
\text { receptor }\end{array}$ & Activated & 2,000 & $\begin{array}{l}5,94 \mathrm{E}- \\
10\end{array}$ & NANOG, POU5F1, SOX2, SRC \\
\hline & TNF & cytokine & Activated & 2,089 & 0,00456 & $\begin{array}{l}\text { KLF4, MYC, NOTCH1, WNT3A, } \\
\text { WNT5A }\end{array}$ \\
\hline & MET & kinase & Activated & 2,219 & $\begin{array}{l}1,29 \mathrm{E}- \\
08\end{array}$ & $\begin{array}{l}\text { KLF4, MYC, NANOG, POU5F1, } \\
\text { SOX2 }\end{array}$ \\
\hline & KLF4 & $\begin{array}{l}\text { transcription } \\
\text { regulator }\end{array}$ & Activated & 2,120 & $\begin{array}{l}1,15 \mathrm{E}- \\
10\end{array}$ & $\begin{array}{l}\text { KLF4, MYC, NANOG, NOTCH1, } \\
\text { POU5F1, SOX2, WNT5A }\end{array}$ \\
\hline & FOXM1 & $\begin{array}{l}\text { transcription } \\
\text { regulator }\end{array}$ & Activated & 2,202 & $\begin{array}{l}1,73 \mathrm{E}- \\
08\end{array}$ & $\begin{array}{l}\text { FZD1, MYC, NANOG, POU5F1, } \\
\text { SOX2 }\end{array}$ \\
\hline \multirow[t]{11}{*}{ BCSC } & CCN2 & growth factor & Activated & 2,186 & $\begin{array}{l}4,42 \mathrm{E}- \\
09\end{array}$ & $\begin{array}{l}\text { FZD2, MYC, NANOG, POU5F1, } \\
\text { SOX2 }\end{array}$ \\
\hline & PRMT1 & enzyme & Activated & 2,000 & $\begin{array}{l}2,45 E- \\
08\end{array}$ & KLF4, NANOG, POU5F1, SOX10 \\
\hline & EGF & growth factor & Activated & 2,149 & $\begin{array}{l}0,00001 \\
42\end{array}$ & $\begin{array}{l}\text { MYC, NANOG, NOTCH1, } \\
\text { POU5F1, SOX2 }\end{array}$ \\
\hline & Usp17la (includes others) & peptidase & Activated & 2,235 & $\begin{array}{l}6,96 \mathrm{E}- \\
13\end{array}$ & $\begin{array}{l}\text { KLF4, MYC, NANOG, POU5F1, } \\
\text { SOX2 }\end{array}$ \\
\hline & USP17L2 (includes others) & peptidase & Activated & 2,236 & $\begin{array}{l}5,68 \mathrm{E}- \\
15\end{array}$ & $\begin{array}{l}\text { KLF4, MYC, NANOG, POU5F1, } \\
\text { SOX2 }\end{array}$ \\
\hline & MYC & $\begin{array}{l}\text { transcription } \\
\text { regulator }\end{array}$ & Activated & 2,012 & $\begin{array}{l}0,00005 \\
45\end{array}$ & $\begin{array}{l}\text { KLF4, MYC, NANOG, POU5F1, } \\
\text { SOX2, WNT5A }\end{array}$ \\
\hline & glutamine & $\begin{array}{l}\text { chemical - } \\
\text { endogenous } \\
\text { mammalian }\end{array}$ & Inhibited & $-2,353$ & $\begin{array}{l}2,86 \mathrm{E}- \\
11\end{array}$ & $\begin{array}{l}\text { KLF4, MYC, NANOG, POU5F1, } \\
\text { SOX10, SOX2 }\end{array}$ \\
\hline & $\begin{array}{l}\text { miR-34a-5p (and other } \\
\text { miRNAs w/seed GGCAGUG) }\end{array}$ & mature microRNA & Inhibited & $-2,168$ & $\begin{array}{l}1,39 E- \\
08\end{array}$ & $\begin{array}{l}\text { KLF4, MYC, NOTCH1, POU5F1, } \\
\text { SOX2 }\end{array}$ \\
\hline & RARG & $\begin{array}{l}\text { ligand-dependent } \\
\text { nuclear receptor }\end{array}$ & Inhibited & $-2,000$ & $\begin{array}{l}1,93 \mathrm{E}- \\
09\end{array}$ & $\begin{array}{l}\text { KLF4, MYC, NANOG, POU5F1, } \\
\text { SOX2 }\end{array}$ \\
\hline & napabucasin & chemical drug & Inhibited & $-2,621$ & $\begin{array}{l}4,05 \mathrm{E}- \\
15\end{array}$ & $\begin{array}{l}\text { KLF } 4 \text {, MYC, NANOG, NOTCH1, } \\
\text { POU5F1, SMO, SOX } 2\end{array}$ \\
\hline & tretinoin & $\begin{array}{l}\text { chemical - } \\
\text { endogenous } \\
\text { mammalian }\end{array}$ & Inhibited & $-2,103$ & $\begin{array}{l}0,00000 \\
16\end{array}$ & $\begin{array}{l}\text { KLF4, MYC, NANOG, NOTCH1, } \\
\text { POU5F1, SOX2, WNT3A, WNT5A }\end{array}$ \\
\hline
\end{tabular}

DNA/RNA transcription as well as growth of tumor were down-regulated in BSC and GBM, DEGs regulated inhibition of apoptosis and aplasia/hypoplasia in BCSC. The canonical pathways are necessary for normal neural development but their upregulation also supports oncogenic phenotype (17).

\section{CONCLUSION}

It has been determined by gene expression profile and pathway analysis that anastasis, a recently described phenomenon, is a factor that promote the oncogenic properties of malignant cells especially brain cancer stem cells. It is clear that inhibition of anastasis may be a significant therapeutic potential for incurable cancers that have been overlooked hitherto.

Conflict of interest: The authors declare that there is no conflict of interest regarding the publication of this paper.

Peer-review: Externally peer-reviewed. 


\section{REFERENCES}

1. Galluzzi L, Vitale I, Aaronson SA, et al. Molecular mechanisms of cell death: Recommendations of the Nomenclature Committee on Cell Death 2018. Cell Death and Differentiation. 2018; 25(3):486-541.

2. Tang HM, Tang HL. Anastasis: Recovery from the brink of cell death. Royal Society Open Science. 2018;5(9):180442.

3. Gudipaty SA, Conner CM, Rosenblatt J, Montell DJ. Unconventional Ways to Live and Die: Cell Death and Survival in Development, Homeostasis, and Disease. Annual Review of Cell and Developmental Biology. 2018 ;34:311332.

4. Naik S, Larsen SB, Cowley CJ, Fuchs E. Two to Tango: Dialog between Immunity and Stem Cells in Health and Disease. Cell. 2018;175(4):908920.

5. Takahashi K, Yamanaka S. Induction of Pluripotent Stem Cells from Mouse Embryonic and Adult Fibroblast Cultures by Defined Factors. Cell. 2006; 126(4):663-76.

6. Komiya $Y$, Habas R. Wnt signal transduction pathways. Organogenesis. 2008; 4(2):68-75.

7. Kuşoğlu A, Biray Avcı Ç. Cancer stem cells: A brief review of the current status. Gene. 2019;681:80-85.

8. Sharifzad F, Ghavami S, Mardpour S, et al. Glioblastoma cancer stem cell biology: Potential theranostic targets. Drug Resistance Updates. 2019;42:35-45.

9. Fiscon G, Conte F, Licursi V, Nasi S, Paci P. Computational identification of specific genes for glioblastoma stem-like cells identity. Scientific Reports. 2018; 8(1):10593.

10. Mazzoldi EL, Pastò A, Pilotto G, et al. Comparison of the Genomic Profile of Cancer Stem Cells and Their Non-Stem Counterpart: The Case of Ovarian Cancer. Journal of Clinical Medicine. 2020; 9(2):368.

11. Kuciak M, Mas C, Borges I, Sánchez-Gómez $P$, Ruiz i Altaba A. Chimeric NANOG repressors inhibit glioblastoma growth in vivo in a contextdependent manner. Scientific Reports. 2019; 9(1):3891.

12. Hu B, Wang $Q$, Wang $Y A$, et al. Epigenetic Activation of WNT5A Drives Glioblastoma Stem Cell Differentiation and Invasive Growth. Cell. 2016;167(5):1281-1295.e18.
13. Yi $Y$, Hsieh IY, Huang $X$, Li J, Zhao W. Glioblastoma stem-like cells: Characteristics, microenvironment, and therapy. Frontiers in Pharmacology. 2016;7:477.

14. Wang J, Wang H, Li Z, et al. C-Myc is required for maintenance of glioma cancer stem cells. PLoS ONE. 2008;3(11):e3769.

15. Swartling FJ. Myc proteins in brain tumor development and maintenance. Upsala Journal of Medical Sciences. 2012;117(2):122-31.

16. Lathia JD, Mack SC, Mulkearns-Hubert EE, Valentim CLL, Rich JN. Cancer stem cells in glioblastoma. Genes and Development. 2015; 29(12): 1203-1217.

17. VanderVorst $\mathrm{K}$, Hatakeyama J, Berg A, Lee H, Carraway KL. Cellular and molecular mechanisms underlying planar cell polarity pathway contributions to cancer malignancy. Seminars in Cell and Developmental Biology. 2018; 81:78-87.

18. VanderVorst K, Hatakeyama J, Berg A, Lee H, Carraway KL. Cellular and molecular mechanisms underlying planar cell polarity pathway contributions to cancer malignancy. Seminars in Cell and Developmental Biology. 2018; 81:78-87. 